\title{
Advantages of compartmented anoxic/ anaerobic selectors in advanced SBR-based biological wastewater treatment plants: A review
}

\#1 Department of Civil Engineering, Indian Institute of Technology Roorkee, Roorkee, Uttarakhand, India-247667

\#2 Department of Civil Engineering, Indian Institute of Technology Roorkee, Roorkee, Uttarakhand, India-247667

The paper aims to analyze and evaluate the benefits of multi-cell or compartmented anoxic/ anaerobic bio-selectors in the performance of sophisticated sequential batch reactors based sewage treatment plants for excellent sewage sludge settling characteristics (lower SVI $<120 \mathrm{~mL} / \mathrm{g}$ ) and significant scope for enhancing biological nutrient (TN and TP) removal efficiencies. The combination of return activated sludge (RAS) and a high amount of soluble, biodegradable substrate from influent sewage in the first compartment of a multi-sectional selector helps select floc-formers against filamentous organisms. It also offers improved results for Simultaneous nitrification and denitrification (SND). Also, it exhibits a platform for direct denitrification of residual nitrates from RAS and considerable phosphorus release during the biological phosphorus removal (BPR or Bio-P) process if proper operational conditions prevail in the plant. Several operating conditions need to be accessed and optimized for improving SND and BPR processes by bio selection mechanisms. They include dissolved oxygen (DO), oxidation-reduction potential (ORP), $\mathrm{pH}$, and influent sewage parameters like fractions of readily biodegradable chemical oxygen demand to TN or TP ratios (rbCOD: TN and rbCOD: TP), soluble COD (sCOD), total COD, $\mathrm{BOD}_{5}$, and incoming volatile fatty acids (VFA) concentrations in the influent wastewater which plays phenomenal roles in achieving the high nutrient removal efficiencies in the plants.

\section{Keywords:}

Simultaneous nitrification and denitrification, biological phosphorus removal, oxidationreduction potential, dissolved oxygen, return activated sludge, readily biodegradable chemical oxygen demand.

Corresponding Author: Srivastava G. (Ghazal Srivastava)

Email id: ghazalsrivastava1247@gmail.com

\section{INTRODUCTION}

Sequencing Batch reactors (SBR) technology is regarded as an alternative to conventional systems like conventional activated sludge processes for eliminating nutrients from sewage. SBR technology thrives in being applied in small wastewater treatment plants treating urban (Puig et al., 2007) and industrial (Vives et al., 2003) wastewaters. It is especially suitable for places with the considerable flow and load variability or where space 
difficulties are restricted (Metcalf and Eddy, 2003). Nutrient removal in SBR needs a combination of anaerobic-anoxic-aerobic phases. The mixed liquor suspended solids (MLSS), carbon, and nutrient ( $\mathrm{N}$ and $\mathrm{P}$ ) concentrations have been considered essential along with other parameters such as food to microorganisms ratio $(\mathrm{F} / \mathrm{M})$ and simultaneous nitrification and denitrification (SND) (Wang et al., 2009, Magdum et al., 2015). The role of microbes is very crucial in the SBRs, such as the role of nitrifiers, denitrifiers, and polyphosphate accumulating organisms (PAOs) together with phenomena such as SND and enhanced biological phosphorus removal (EBPR) (Kim et al., 2008).

Conventional SBRs are devoid of the selector zone, which helps numerous areas in their efficient advancement. The advanced type of sequencing batch reactors (improved technology than conventional SBR) for effective sewage treatment incorporates two zones: 'zone 1' signifies a multi-cell selector zone, and 'zone 2' represents the main aeration zone (Fig 1). The multi-cell selector zone is an incorporating basin or channel where return activated sludge (RAS) and influent wastewater (consisting of high readily biodegradable $\mathrm{COD}(\mathrm{rbCOD})$ or soluble $\mathrm{BOD}_{5}\left(\mathrm{sBOD}_{5}\right)$ content) mix before the aeration basin (Goronszy et al., 1999). Efficacious studies represent a one-fourth to half an hour of contact time for the RAS flow, and influent wastewater is aerated and attains more than $\sim 80 \%$ removal of sBOD $_{5}$ through the selector and almost complete removal of rbCOD (Xin et al., 2008). The purpose is to grant a short-term, high substrate condition that supports certain floc-formers but counteracts filaments with excellent-settling biomass of low sludge volume index (SVI).

Aeration intensity is regulated during the aeration sequence by dissolved oxygen (DO) and oxygen uptake rate (OUR) control to ensure the optimum low value of redox potential during air-off operation to favor nitrogen and phosphorus removal mechanisms. The confined selector assures a feed-starve contact of the biomass, which is obligatory to promote the enzymatic transfer of soluble substrate and following conversion to storage compounds, which are essential to prevent the filamentous sludge bulking (Goronszy and Eckenfelder, 1988). This feature effectively removes the dependency on the fill-ratio operation to generate in-basin selector mechanisms practiced in other sequencing batch systems (Goronszy 1992). Denitrification and enzymatic transfer of available substrate during enhanced biological phosphorus release are also achieved in the anaerobic selector zone.

The three crucial roles of the anoxic/ anaerobic biological selectors are the following (Minnesota Pollution Control Agency, 2006)-

1) It generates an anoxic/ anaerobic environment for the denitrification of nitrates to occur (coming from the RAS).

2) It suppresses filaments from propagating by introducing anoxic fill conditions so that the natural selection of floc-forming bacteria can occur, resulting in exceptional sludge settling characteristics.

3) The soluble organics in the raw sewage are sequestered as intracellular compounds in the biomass. The stored substrate is then used for simultaneous nitrification and denitrification (SND) and biological phosphorus removal (BPR/ Bio-P) in managed cyclic aeration sequences in a sequencing batch reactor in the aeration zone.

Nitrate penetration is governed by its diffusion rate, which is of the order of ten times that of DO. Under aerated provisions, there is usually no nitrate constraint in the inner zone of the floc. Sufficient carbon availability for denitrification is accomplished through the carbon storage (biosorption- PHB) mechanism. The process can be regulated such that during the aeration phase, there is nitrification and denitrification taking place inside the bigger flocs. On the periphery of the sludge floc, nitrification prevails, and in the anoxic zones towards the center of the floc, denitrification occurs. Denitrification also takes place during the settling phase. Process control using in-basin respiration enables direct control over BPR. 
a

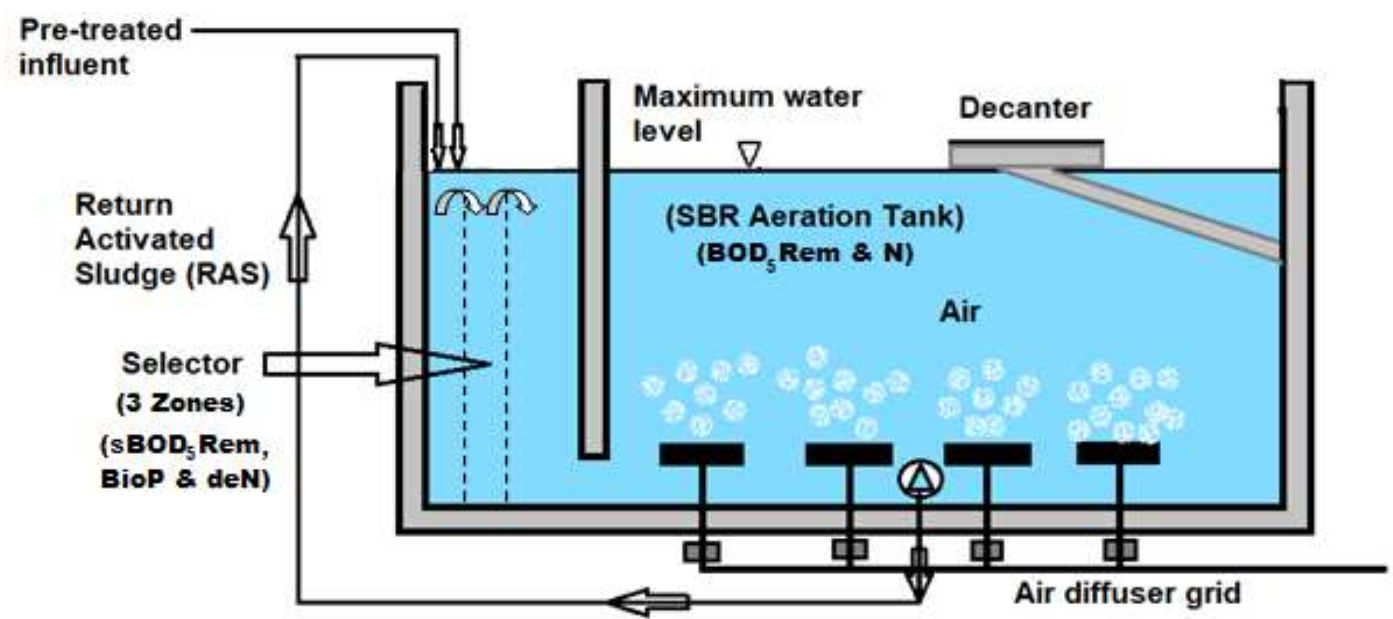

$\mathbf{b}$
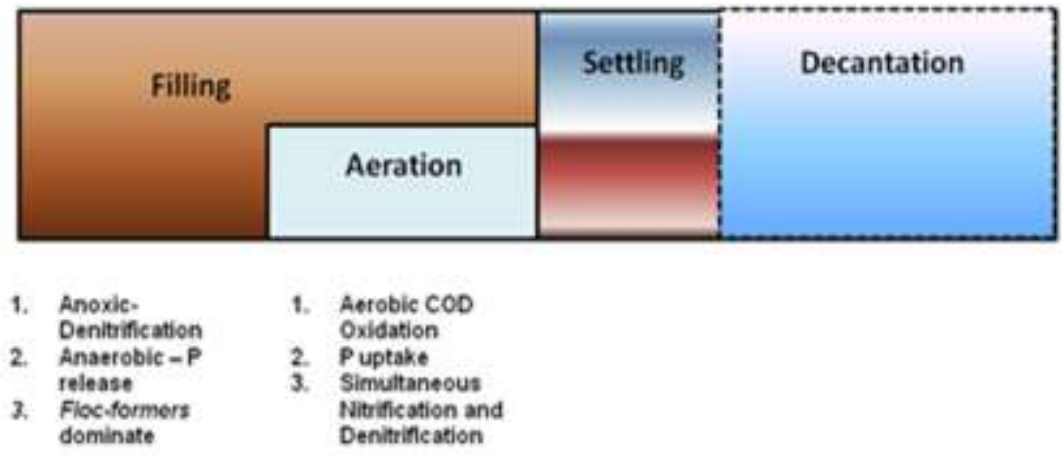

Fig 1: (a) Schematic diagram of pre-anoxic tri-sectional selectors based SBR plant (b) Processes occurring in different phases (sections) of an SBR plant.

\section{OBJECTIVE}

The literature confirms that using a natural biological selection mechanism, bulking sludge conditions are controlled, the aeration and clarification capacity increases, the operation becomes further stable, effluent quality improves, and the process is trouble-free to manage. However, lesser literature is available demonstrating the selector's capacity to enhance nutrient removal by SND and BPR processes after optimizing the favorable conditions for microbiota governing these mechanisms. This review paper can throw light on some broad aspects of using bio selection mechanisms in nutrient removal while maintaining sludge settling characteristics concomitantly.

Thus, the overall study focuses on the role of selectors in the advancement of SBRs, which constitutes the three main objectives:

- Impacts of designing the multi-compartment selectors on reducing sludge volume index (SVI) and improvising the sludge settling characteristics, floc size, and microbial biomass composition.

- Anoxic bio-selectors' performance in biological nutrient (N and $\mathrm{P}$ ) removal via SND and BPR (Bio-P) processes.

- The influence of operational factors/ parameters in optimizing the treatment systems includes $\mathrm{DO}, \mathrm{pH}, \mathrm{ORP}$, and availability of volatile fatty acids (VFAs) (via fermentation of rbCOD). 


\section{RESEARCH METHODOLOGY}

The present review demonstrates an efficient and tentative means to investigate the bio-selectors' role in enhancing the inner processes, including SND and BPR, and simultaneously augment the sludge settling characteristics in the highly developed SBR systems. The information in this study is derived from the secondary data, and the secondary data source is collected using published articles, journals, books, the Internet, seminar materials, and web technologies, etc.

\section{RESULTS AND DISCUSSION}

\section{(i) Bio-selectors design variables}

The system is planned so that the sludge return rate originates from the approximate daily cycling of the total biomass through the selector zone. The mechanism in zone 1 and the internal sludge transfer remove the obligation for separate fill-ratio selectivity, anoxic, and anaerobic mixing periods necessary for the matured generic SBR configurations. The main reactor's absolute-mix nature provides flow and load balancing and tolerance to alarmed or toxic loading. The practice prevents solids washout during peak or wet weather hydraulic surges, which are not possible in conventionally designed clarifier activated sludge plants. It combines both aerobic-anaerobic phases in one unit and saves up to $25 \%$ of the aeration costs simultaneous with low sludge production.

If $\mathrm{N}$ removal without BPR is the main objective, the system should be operated with the shortest possible cycle time at high recycle ratios. However, if both BPR and N removal is required, a longer cycle time should be selected to operate with the minimum (sludge) recycle ratio (Singh et al., 2010).

Generally, in superior selector based SBR plants (where RAS mixes with the influent sewage), selectors are designed considering the numerous factors (SFC Environmental Technologies Pvt Ltd., 2020). Firstly, the contact time should be around 20-60 minutes (Metcalf and Eddy, 2003). Secondly, a baffle wall arrangement is offered in the selector to create several compartments (multi-cell) to mix arriving sewage with return sludge in a plug flow arrangement. Thirdly, each compartment's surface area in the selector is designed as sufficient vertical up-flow velocity is accessible to avoid sludge settlement (hence it is not similar to the primary sedimentation tank in SBRs). Vertical up-flow velocity should be five times the sludge settling velocity. Also, horizontal scouring velocity should be greater than $0.3 \mathrm{~m} / \mathrm{s}$ to avoid settlement and also to ensure sufficient mixing. Fourth, a coarse air bubble grid is installed in the selector compartments of each basin, which is used to agitate and remove any accumulated suspended solids that want to settle in the selector compartment during the settling/ decanting phase when there is no inflow into the basin. The selector air valve is set to operate for 5 minutes at the start of each fill cycle. Finally, the selector cells are operated without aeration and are self-mixed under baffle 'jet' entrainment mixing. Mixing and vertical velocities exceed industry practice for scouring and solids deposition in pipelines and settling basin design.

In combination, the cells are in continuous fluid communication and hence function as a plug flow reactor, which is, by definition, an equivalent number of completely mixed reactors in series connection. It should be considered that the attached references do not contain any purpose sized mixing equipment or any sequences of operation devoted to nonaerated mixing (Goronszy 1992, Goronszy 1996). This is an advancement of the SBR from conventional SBR. It serves as a medium-as un-aerated fill time and purpose placed and operated mixer demanded by using that more complex alternative. This is a prerequisite for the SND and enhanced BPR processes. Conditions rapidly proceed to anaerobic in the later cells of the unaerated selector. By design and purpose of operation, the net reaction conditions of the selector's flow into the aeration zone having an ORP below $0 \mathrm{mV}$. 
(ii) Role of compartmentalization in bulking control and biological nutrient removal

In many cases, selectors can be installed within existing basins as a series of small compartments using $6 \%$ to $10 \%$ of the total aeration volume. The deficiency of this aeration tank volume is easily neutralized by the amplified MLSS and solids loading rates resulting from the modified process of the system at a lesser SVI.

The selectors most frequently consist of three/ four complete mix activated sludge reactors (zones) in a series for the initial contact of the return sludge and the influent wastewater to be treated. These small compartments will grant an F/M gradient, which has been revealed to be the essential feature in the environmental conditions benefitting in producing a non-bulking sludge. The general arrangement of bio selectors for an advanced wastewater treatment plant is shown in Fig 2. Mixing and aeration are provided by diffuser aeration. Heide and Pasveer (1974) displayed effective bulking sludge control by recycling oxidized MLSS from a subsisting oxidation ditch and interfacing the MLSS with raw wastewater in a six-stage external selector. There is an option for biological phosphorus removal (Bio-P), and the anoxic zone allows for the removal of the nitrates (denitrification) in the internal recycle (IR) stream. When nitrification $(\mathrm{N})$ and denitrification $(\mathrm{deN})$ are not required, the anoxic zones after the selectors and internal recycling are not employed. However, the selectors are equally effective in controlling bulking in conventional secondary treatment.

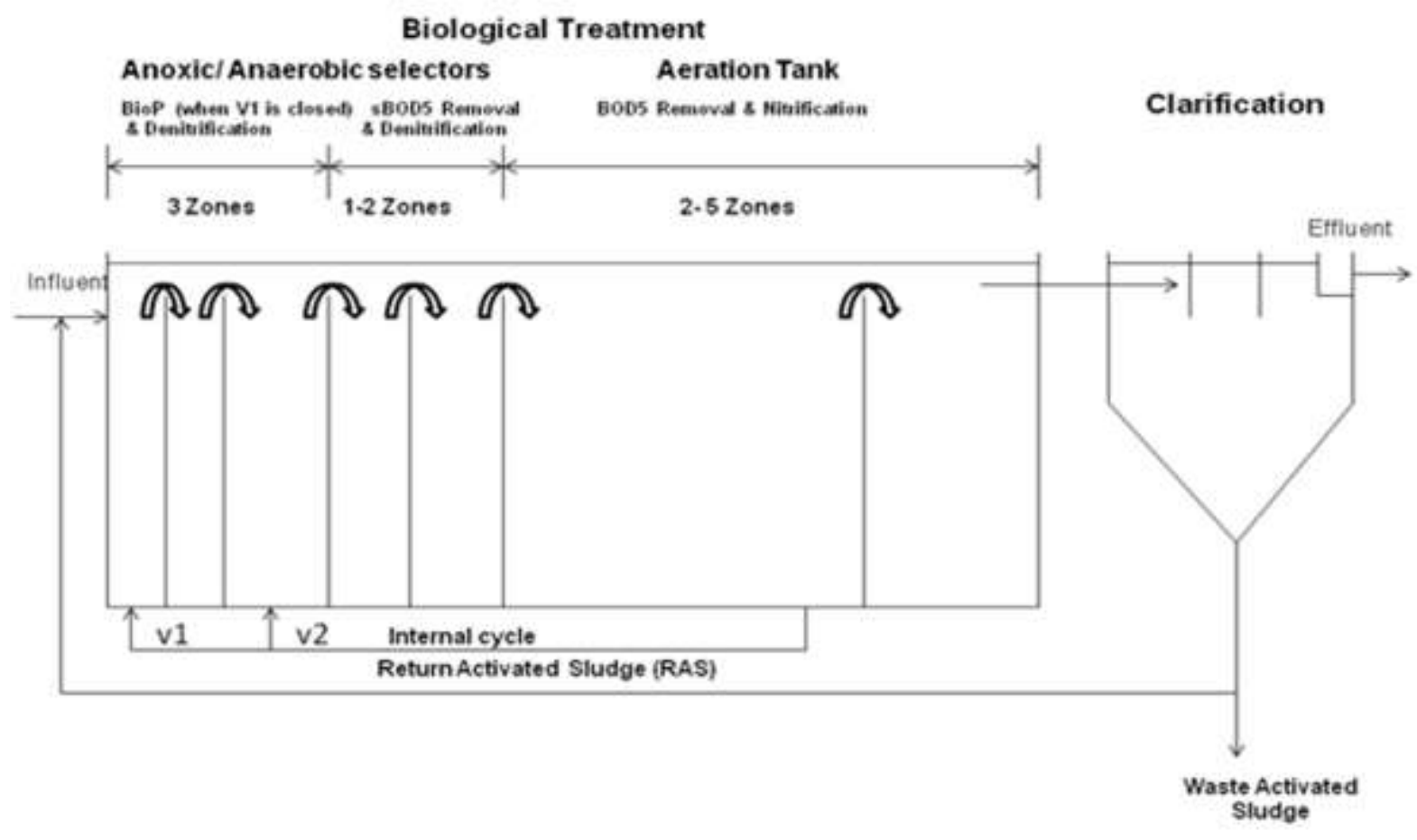

Fig 2: Semi-Aerobic Process for Bulking Control and Nutrient Removal by Heide and Pasveer (1974)

The compartment sizing of the selectors to generate an F/M gradient has evolved considerably. Still, the general mechanistic concept of selection using an F/M gradient initially presented by Chudoba et al. (1973a, 1973b, 1974) and the design of Heide and Pasveer (1974) is regarded as appropriate. It is essential to eliminate unmanaged back mixing between the selector zones (Albertson 2002). The design should employ submerged walls to prevent floating material capture in the compartments. The anoxic selectors require lesser F/M than aerobic selectors (Table1). 
Table1. Three types of selector designs (Metcalf and Eddy 2003)

\begin{tabular}{|c|c|c|c|}
\hline Design Parameters & Aerobic Selector & Anoxic Selector & Anaerobic Selector \\
\hline$(\mathrm{F} / \mathrm{M})_{\mathrm{i}}$ & $\begin{array}{l}\text { For the first stage } \\
\text { loading control of } \\
\text { viscous bulking: } \\
8 \sim 12 \mathrm{~g} \text { COD/ } \mathrm{g} \\
\text { MLSS. day } \\
\text { The general } \\
\text { fraction of F/M: } \\
\text { 12/6/3 } \mathrm{g} \text { COD/g } \\
\text { MLSS .day }\end{array}$ & $\begin{array}{c}\text { 6/3/1.5 g COD/g } \\
\text { MLSS .day }\end{array}$ & $\begin{array}{l}\text { For first stage loading } \\
\text { control of viscous } \\
\text { bulking: }<6 \mathrm{~g} \text { COD/g } \\
\text { MLSS. day } \\
\text { Verification is required } \\
\text { for the smallest } \\
\text { compartment (fraction } \\
1 \text { in } 1 / 1 / 2 \text { ). }\end{array}$ \\
\hline $\begin{array}{l}\text { Hydraulic retention } \\
\text { times }(\mathrm{HRT})\end{array}$ & 10-20 minutes & $\begin{array}{c}\sim 60 \text { minutes (for } \\
\text { municipal } \\
\text { wastewater) }\end{array}$ & $45-120$ minutes \\
\hline $\begin{array}{c}\text { Reactor staging } \\
(1 / 1 / 2)\end{array}$ & Required & $\begin{array}{l}\text { May be/ may not } \\
\text { be required. }\end{array}$ & Required \\
\hline Internal recycle & - & $\begin{array}{l}\mathrm{NO}_{3}^{-} \text {supplied by } \\
\mathrm{RAS} \text { and mixed } \\
\text { liquor recycling }\end{array}$ & No \\
\hline Denitrification rate & - & $\begin{array}{l}5 \sim 10 \mathrm{mg} \mathrm{\textrm {NO } _ { 3 } -}-\mathrm{N} / \mathrm{g} \\
\left.\text { MLSS.hr (at } 20^{\circ} \mathrm{C}\right)\end{array}$ & $\begin{array}{l}\text { Rapid denitrification } \\
\text { rates same as anoxic } \\
\text { selectors }\end{array}$ \\
\hline Mixing/ aeration & Aeration & Mixing & Mixing \\
\hline $\begin{array}{c}\text { Number of } \\
\text { compartments }\end{array}$ & Three (1/1/2) & Three (1/1/2) & Three (1/1/2) \\
\hline
\end{tabular}

Donaldson (1932a, 1932b) has distinguished filaments as the 'weeds of activated sludge,' appropriately examined that backflow mixing of long and rectangular (plug flow) basins contributed to the development of filaments and therefore proposed to baffle the aeration basin into different compartments. British Water Pollution Laboratory (1969), Bhatla (1967), and Ryder (1973) all analyzed that low DO in the preliminary zone of aerated, extended, rectangular staged basins (selector) would be helpful in offering bulking control. Koller (1966) and Pasveer (1969) rediscovered that intermittent supplying of batch reactors would limit filamentous organisms' growth. The researchers further observed that the organic loading gradient in the initial compartments of the treatment process was the solution to bulking sludge control. The effect of compartmentalization on SVI from their studies is exhibited in Fig 2. As the number of compartments was expanded in the biological reactor, the maximum level of soluble chemical oxygen demand (sCOD) in the MLSS increased in the first compartment (Table 2). The presence of 70 to $120 \mathrm{mg} / \mathrm{L}$ sCOD due to an increased F/M in the smaller initial contact zone (ICZs) was an important factor in the control of bulking organisms. Rensink (1974) also confirmed earlier investigators' observations regarding the benefits of staging the reactor zones to reduce sludge bulking.

While selectors will cause the removal of the bulk of the simple organics (alcohols, volatile acids, sugars, and amino acids) from solution before anoxic or oxic zones, the hydrolysis of colloidal and suspended organics in the following oxic zones may present an opportunity for filamentous organisms to nourish and develop. This phenomenon was introduced as 'secondary bulking' by Wanner and Grau (1988). Therefore they recommended a high to low F/M gradient (compartmentalization) in the aeration zones. This postulation may confirm why selectors are very useful when treating highly soluble industrial wastewater 
flows. The bulk of the influent $\mathrm{COD}$ (or $\mathrm{BOD}_{5}$ ) is removed in the selectors, and the byproducts of hydrolysis of the low level of particulates in the oxic zone are minimal. Thus, secondary bulking cannot occur, and this could be the reason that very low SVIs (20 to 50 $\mathrm{mL} / \mathrm{g}$ ) have been accounted for (Davidson, 1957; Okey, 1997) when treating extremely soluble industrial wastewaters including typically low molecular weight organics.

Table2. General design guidelines for selector sizing for aerated and anoxic selectors (after Albertson 2002)

\begin{tabular}{|c|c|c|c|}
\hline \multicolumn{4}{|c|}{ Zone wise F/M } \\
\hline & $\begin{array}{ll}S_{x}-1 & \left(1^{\text {st }}\right. \\
\text { compartment })\end{array}$ & $\begin{array}{ll}S_{x}-2 & \left(2^{\text {nd }}\right. \\
\text { compartment })\end{array}$ & $\begin{array}{ll}S_{x}-3 & \left(3^{\text {rd }}\right. \\
\text { compartment })\end{array}$ \\
\hline $\mathrm{Kg} \mathrm{COD} / \mathrm{Kg} \mathrm{d}$ & $10-12$ & $5-6$ & $2.5-3$ \\
\hline$* \mathrm{Kg} \mathrm{sCOD} / \mathrm{Kg} \mathrm{d}$ & $5-6$ & $2.5-3$ & $1.25-1.5$ \\
\hline $\mathrm{Kg} \mathrm{BOD}_{5} / \mathrm{Kg} \mathrm{d}$ & $5-6$ & $2.5-3$ & $1.25-1.5$ \\
\hline$* \mathrm{Kg} \mathrm{sBOD}_{5} / \mathrm{Kg} \mathrm{d}$ & 2.5 & 3 & $0.63-0.75$ \\
\hline
\end{tabular}

* Best basis for selectors designing; $\mathrm{COD} / \mathrm{BOD}_{5}$ and $\mathrm{sCOD}_{\mathrm{sBOD}}$ range is presumed to be $1.8-2.2$; the parameter COD, etc., is used such that it generates the least selector volume; and F/M criteria can be reduced if loadings are significantly high.

\section{(iii) Operational parameters in selectors}

The operational parameters in the selectors are $\mathrm{DO}, \mathrm{ORP}, \mathrm{pH}$, temperature, recycle ratios, and HRT. Low DO and high substrate conditions favor floc-formers. Hence, the DO profile enables the SND feature of the process to occur where the fractional intra portion of the biomass is about $50 \%-70 \%$ in the biomass. Other anoxic conditions are also developed in the settle and decant air-off sequence to about $20 \%$ of the sequence time (Goronszy 1992). Generally, in superior SBRs, once OUR and DO levels are measured in the basins, aeration intensity is regulated automatically according to actual demands of the process through the programmable logic controller and variable frequency drive connected to air blower to maintain desired DO levels in the basin. This methodology provides a true-in-basin method for efficient energy use and ensures $20 \%$ - 30\% power savings.

Important to the design proposed is the recommendations that include designing an anaerobic functioning selector for as short a time as possible for which various times of 30 to 45 minutes are suggested. In the multi-cell selector technology used in advanced SBRs, each cell has a design retention time of 60 minutes for acceptable and proven floc loadings. A DO concentration of $\geq 0.2 \mathrm{mg} / \mathrm{L}$ has been stated to hinder denitrification for a pseudomonas culture (Skerman and MacRae (1957), Dawson and Murphy (1972)) for activated sludge treating wastewater. Denitrification is observed to be ceased in a highly dispersed growth at a DO concentration of $0.13 \mathrm{mg} / \mathrm{L}$ (Metcalf and Eddy, 2003). Rittman and Langeland (1985) reported that more than $90 \%$ removal of nitrogen in an activated sludge system for treating municipal wastewater occurs by SND at a higher HRT of greater than 25 hours (and high $\mathrm{SRT}$ ) in the complete SBR process. Dissolved oxygen should be kept $<1 \mathrm{mg} / \mathrm{L}$ in the anoxic/ anaerobic selector, and the nitrate supply should be within the range of $6-8 \mathrm{~kg} / \mathrm{kg}$ COD or 3$5 \mathrm{~kg} / \mathrm{kg}$ of $\mathrm{BOD}_{5}$. The HRT in the selectors should be around 60 to 90 minutes (Harper and Jenkins, 2003; Metcalf and Eddy, 2003). It is also suggested that the aeration basin (main SBR tank) be designed so that DO never drops below $1.0 \mathrm{mg} / \mathrm{L}$; otherwise, it can increase the SVI levels (Pitman 1991).

For Phosphorus removal (BPR), biomass needs anaerobic-aerobic sequencing, whereas, for Nitrogen removal and SND, it needs aerobic- anaerobic sequencing. Therefore repetitive and designed sequencing as anaerobic/ anoxic/ aerobic within the water line fulfills 
all of the requirements for both Bio-P and nitrogen removal in the activated sludge process and entirely complies with the spirit and intent of the selector based SBR systems. Aeration should be more than sufficient to provide for the sequestering of phosphorous following the enhanced BPR mechanisms.

The sequencing is achieved in the overall given cycle time. It takes place in an approximate sinusoidal format during the fill-anoxic (/anaerobic) phase in the selectors to oxic and then settling and decanting phase in the aeration basin as $-120 \mathrm{mV}$ to $-150 \mathrm{mV}$ to about $+200 \mathrm{mV}$ and down to about $-120 \mathrm{mV}$ to $-150 \mathrm{mV}$, which is repeated continuously by the repetitive cycle of operation (i.e., fill, aeration, settle, decant) (Fig 3). However, recent studies suggest that ORP values of less than $-50 \mathrm{mV}$ are needed to denitrify effectively. The ORP readings of $-75 \mathrm{mV}$ to $-100 \mathrm{mV}$ have been examined to attain complete denitrification of the nitrates (Ron Trygar 2009). The necessary wastewater conditions of enhanced BPR process regarding total, soluble, readily biodegradable COD to $\mathrm{P}$ ratios are observed in the studies of Mino et al., 1998 and Barnard et al., 2007. ORP should reach the ranges of negative values up to $-200 \mathrm{mV}$ in the anaerobic zone, between $-50 \mathrm{mV}$ to $+50 \mathrm{mV}$ in the anoxic phase, and positive values up to $+300 \mathrm{mV}$ in the oxic zones (Burkhardt 2012). The metabolic processes at different ORP ranges are shown in Table 3.

Table3. Different ORP ranges and metabolic processes occurring during the treatment of wastewater after Goronszy (1992)

\begin{tabular}{|c|c|c|c|c|}
\hline $\begin{array}{l}\text { S. } \\
\text { No. }\end{array}$ & Process & $\begin{array}{c}\text { Approximate ORP } \\
\text { Range }(\mathrm{mV})\end{array}$ & $\begin{array}{l}\text { Electron } \\
\text { Acceptors }\end{array}$ & Conditions \\
\hline 1 & Organic carbon oxidation & $\sim+50$ to $\sim+220$ & $\mathrm{O}_{2}$ & Oxic or Aerobic \\
\hline 2 & $\begin{array}{c}\text { Polyphosphate } \\
\text { development }\end{array}$ & $\sim 0$ to $\sim+250$ & $\mathrm{O}_{2}, \mathrm{NO}_{3}{ }^{-}$ & $\begin{array}{c}\text { Oxic or Aerobic, } \\
\text { Anoxic }\end{array}$ \\
\hline 3 & Nitrification & $\begin{array}{l}\sim+100 \text { to } \sim+330 \text { (or } \\
>300 \text { ) }\end{array}$ & $\mathrm{O}_{2}$ & Oxic or Aerobic \\
\hline 4 & Denitrification & $\sim-50$ to $\sim+50$ & $\mathrm{NO}_{3}{ }^{-}$ & $\begin{array}{c}\text { Anoxic, } \\
\text { Anaerobic }\end{array}$ \\
\hline 5 & $\begin{array}{c}\text { Polyphosphate } \\
\text { breakdown }\end{array}$ & $\sim-10$ to $\sim-200$ & $\begin{array}{l}\mathrm{NO}_{3}^{-}, \mathrm{SO}_{4}{ }^{2-} \\
\text { Carbonaceous } \\
\text { organics }\end{array}$ & $\begin{array}{c}\text { Anoxic, } \\
\text { Anaerobic, } \\
\text { Fermentative } \\
\text { Anaerobic }\end{array}$ \\
\hline 6 & Sulfide formation & $\sim-50$ to $\sim-250$ & $\begin{array}{c}\mathrm{SO}_{4}{ }^{2-} \\
\text { Carbonaceous } \\
\text { organics }\end{array}$ & $\begin{array}{c}\text { Fermentative } \\
\text { Anaerobic }\end{array}$ \\
\hline 7 & Acid formation & $\sim-90$ to $\sim-220$ & $\begin{array}{c}\mathrm{SO}_{4}{ }^{2-}, \\
\text { Carbonaceous } \\
\text { organics }\end{array}$ & $\begin{array}{c}\text { Fermentative } \\
\text { Anaerobic }\end{array}$ \\
\hline 8 & Methane formation & $\sim-190$ to $\sim-340$ & $\begin{array}{c}\mathrm{SO}_{4}{ }^{2-}, \\
\text { Carbonaceous } \\
\text { organics }\end{array}$ & $\begin{array}{c}\text { Fermentative } \\
\text { Anaerobic }\end{array}$ \\
\hline
\end{tabular}


Anoxic/ Anaerobic phase (selector)
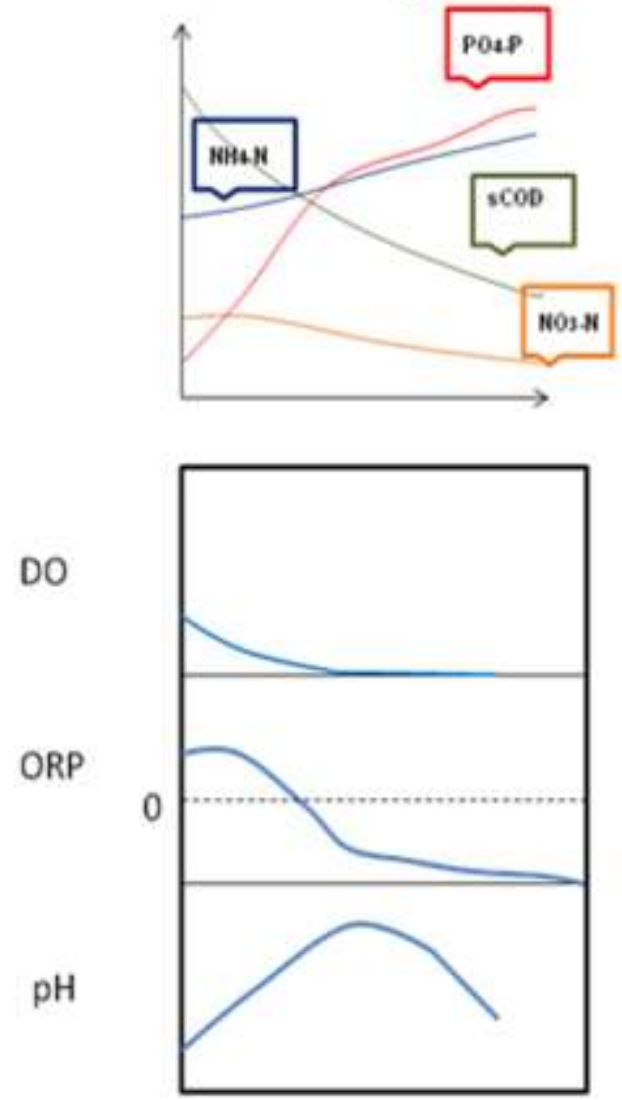

Aeration phase (SBR tank)

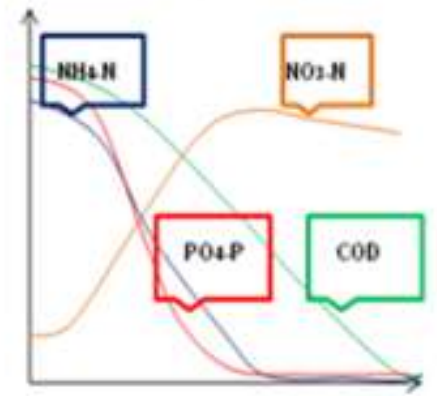

DO

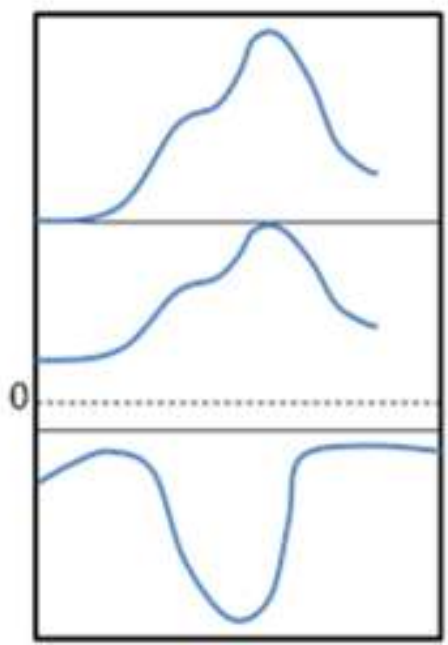

Fig 3: Illustrative patterns of DO, ORP, $\mathrm{pH}$, on substrate removal in general selector based SBRs.

There is also the dependence of anaerobic HRT of selectors and recycle ratios on the plant's phosphorus removal and generally exhibits an increasing relationship (Randall et al., 1992).

\section{(iv)Impact on sludge settling characteristics}

The process benefits of a lower and stable SVI are well known to plant operators. Management of the activated sludge process is simplified, and the effluent quality is more stable with nominal sludge blankets in the clarifier. Also, the biological average and peaking capacities of the biological system are increased. The selector reduced the required aeration volume and clarifier area. Without selectors, the aeration volume would need to be $16.7 \%$ larger, and the clarifier surface area would be raised by $60 \%$. It is expected that the smaller plant with selectors would also produce a better effluent quality (Pitman 1991, Albertson 2002). Furthermore, the process at $\leq 120 \mathrm{~mL} / \mathrm{g}$ SVI will be more stable, produces a higher quality effluent, and will be easier to control. There is a more significant potential for the SVI to increase from $150 \mathrm{~mL} / \mathrm{g}$ to above $250 \mathrm{~mL} / \mathrm{g}$ without selectors, but with selectors, the more probable USVI (unstirred) is $\leq 100 \mathrm{~mL} / \mathrm{g}$ (Albertson 2002, Parker et al., 2003).

\section{(v) SND by the selection of floc-formers}

The selective mechanism is to contact the return activated sludge (RAS) and an internal recycle when employed with the influent wastewater in an initial contact zone (ICZ) of the biological reactor with limited or no molecular oxygen available. In these zones, 
heterotrophs remove the low molecular weight, soluble substrates from the solution. Since the favored substrate (small, soluble organics/molecules) of the filamentous bacteria is limited in the heavily aerated oxic zones following the selectors and anoxic (denitrification) zones (if employed), their growth is inhibited. The presence of a limited quantity of filamentous bacteria is generally desirable as they can help produce a more substantial and larger floc structure (Palm et al., 1980), which will easily settle and compact favorably in the secondary clarifier. The larger floc sizes in the aeration zone help in simultaneous nitrification and denitrification (Bakti and Dick, 1992), as illustrated in Fig 4.

For the SND process to take place in the aeration tanks, denitrifiers need a carbon source $\left(\mathrm{sBOD}_{5}\right.$ or $\left.\mathrm{rbCOD}\right)$, which is made available to them in the ICZ of the selector. Therefore parameters like COD/ TN, $\mathrm{BOD}_{5} / \mathrm{TN}, \mathrm{rbCOD} / \mathrm{TN}$, and $\mathrm{rbCOD} / \mathrm{sCOD}$ all play a significant role in getting higher denitrification rates and SND in the plants (Khursheed et al., 2018).

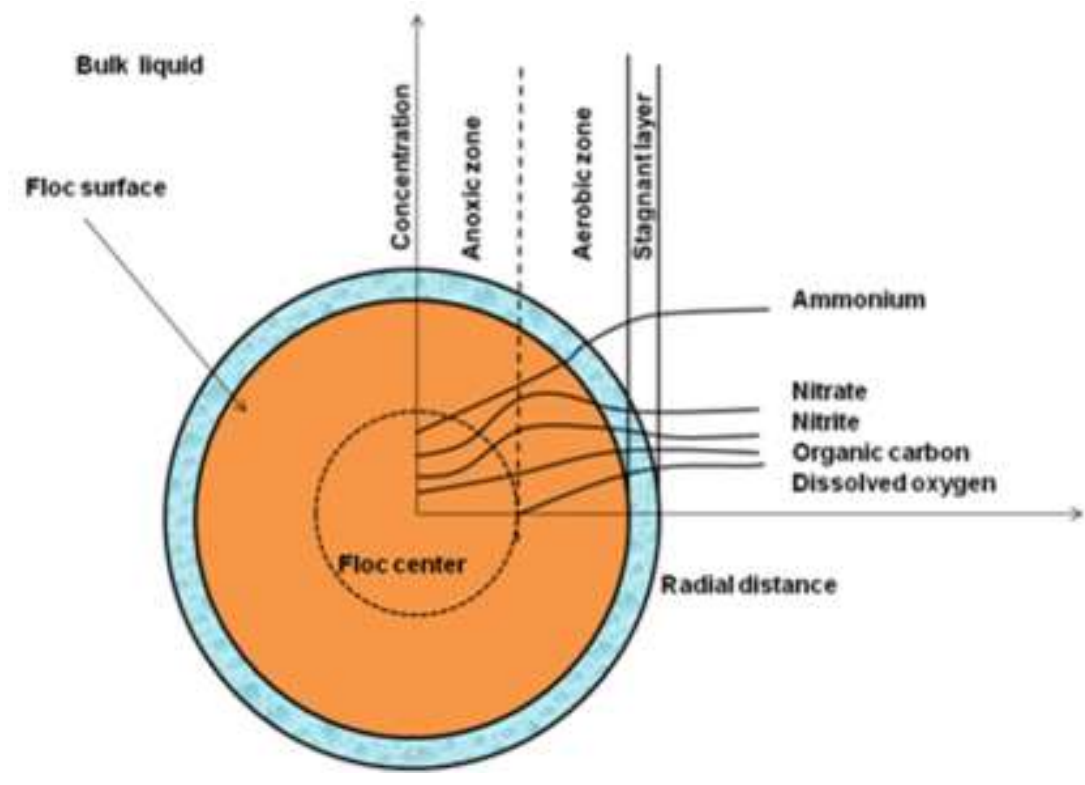

Fig 4: Different substrate concentration profiles in a microbial floc showing simultaneous nitrification and denitrification.

\section{(vi) Scope of BPR in anoxic/ anaerobic selector based SBRs}

The general arrangement of selectors for an advanced wastewater treatment plant displayed in Fig 2 can be an option for biological phosphorus removal (Bio-P). Even the anoxic zone allows for the removal of the nitrates (denitrification) in the internal recycle (IR) stream. Some enhanced biological phosphorus removal can also be perceived intermittently in the anoxic zones if sufficient rbCOD becomes available (Naidoo 2000).

The best performance for Bio-P is with mixing only and without internal recycling. The matter of whether the low DO aeration or anoxic mode results in a smaller, more consistent SVI is yet to be examined. The unaerated volume requirements for Bio-P removal are more extensive than required for bulking sludge control. Bioselectors designed for bulking control, with and without denitrification, will generally reduce the total effluent phosphorus (TP) to 1.5 to $3.0 \mathrm{mg} / \mathrm{L}$, depending on incoming wastewater characteristics and the nitrogen inventory in the system (Albertson 2002).

When denitrification is required, the air rate is more limited in the selectors, and about $30 \%$ to $35 \%$ of the internal recycle (IR) is discharged to the initial contact zone through Valve V1 (Fig 2). If partial (65\% -80\%) phosphorus removal is the target, then the internal 
recycling should be released either to the third selector stage or the anoxic zone after the selector. Further, it is unknown whether the eminent (best) process design for selection and bulking control will permit the optimization of phosphorus removal. Table 4 illustrates that it is desirable to have minimal DO in the influent to the initial contact zone and low nitrates in the RAS. There is no internal recycling of nitrates to the selector zones whenever Bio-P is to be optimized.

The increase in the net biomass yield would, in part, be due to the accumulation of excess phosphorus (Bio-P) in the selector arrangement. While the anaerobic mode provides the highest removal level, Bio-P removal in anoxic and low DO selectors is typically $65 \%$ to $80 \%$. For each surplus $\mathrm{kg}$ of TP removed, about 4 to $4.5 \mathrm{~kg}$ of waste sludge will be produced and increase total waste sludge proportionally. The anaerobic zone volume is often defined by criteria for Bio-P removal, which requires a longer retention time than bulking sludge control. However, lower SVIs are associated with higher phosphorus content in the MLSS (Bio-P) (Albertson 2002).

Wastewater characteristics affect a lot in biological phosphorus removal. Total $\mathrm{COD} / \mathrm{TP}, \mathrm{BOD}_{5} / \mathrm{TP}$, and a readily biodegradable component of COD (rbCOD) to TP ratios play a significant role in biological phosphorus removal in the plants (Broughton et al. 2008, Majed et al. 2019). The readily biodegradable COD undergoes fermentation, and VFA formation occurs. Anaerobic selectors have been flourishingly utilized in plants that are nitrifying. In these cases, the concentration of volatile fatty acids in the influent to the secondary process must be adequate to both support denitrification of the nitrate in the return sludge as well as to sustain the energy cycling of the BioP organisms responsible for choosing against filamentous organisms (Albertson 2002, Parker et al., 2003). VFA should be either present in the wastewater through long anaerobic sewer lines, or rbCOD must be sufficient which can be fermented to VFAs. They are then stored in the form of polyhydroxy butyrate (PHB) simultaneously with phosphorus release by PAOs in the anaerobic zone. Additional uptake of the phosphorus occurs in the aerobic zone, and the stored products (PHB) are utilized for energy in the absence of exogenous substrates (Mino et al., 1998).

Table4. Different types of selectors and their role in biological phosphorus removal

\begin{tabular}{|l|l|l|}
\hline $\begin{array}{l}\text { Type of } \\
\text { selector }\end{array}$ & Conditions & Effects on biological phosphorus removal \\
\hline $\begin{array}{l}\text { Aerated, Low } \\
\text { DO selectors. }\end{array}$ & $\begin{array}{l}\text { Lack of DO in the } \\
\text { initial length of long, } \\
\text { rectangular basins }\end{array}$ & $\begin{array}{l}\text { It is related to the biological removal of phosphorus } \\
\text { (luxury uptake) and the control of SVI. The low DO } \\
\text { in the initial 20\%-30\% of the basin length encourages } \\
\text { biological phosphorus removal (Bio-P removal), as } \\
\text { well as produces reduced SVIs. }\end{array}$ \\
\hline $\begin{array}{l}\text { Anoxic } \\
\text { selectors }\end{array}$ & $\begin{array}{l}\text { DO by aeration or } \\
\text { by recycling of } \\
\text { nitrates to the initial } \\
\text { contact zone. }\end{array}$ & $\begin{array}{l}\text { When oxygen is introduced into the initial contact } \\
\text { zone, the loss of selectivity is noticeable from the } \\
\text { decrease in the level of phosphorus removal in aerated } \\
\text { (high or low) and anoxic selectors. }\end{array}$ \\
\hline $\begin{array}{l}\text { Anaerobic } \\
\text { selectors }\end{array}$ & $\begin{array}{l}\text { No DO } \\
\text { To optimize phosphorus's biological removal, the } \\
\text { introduction of free and combined sources of oxygen } \\
\text { into the selector zone must be minimized. These type } \\
\text { of selectors maximizes the availability of sBOD } \\
\text { (sCOD) for the Bio-P reactions. }\end{array}$ \\
\hline
\end{tabular}

Further, it is unknown whether the best process design for biological selection and bulking control will permit the optimization of phosphorus removal. However, it is desirable 
to have minimal DO in the influent to the ICZ and low nitrates in the RAS. There should include no internal recycling of nitrates to the bio selector zones whenever Bio-P is to be optimized.

\section{(vii) Effects of anoxic selectors on filamentous bacterial growth}

Certain organisms that cause bulking and foaming can be prohibited by using multicell anoxic/ anaerobic selectors (Table 5). But some filamentous growth cannot be controlled if it is caused by either nutrient deficiency (under-loaded condition) or industrial wastewater mixing in raw sewage (higher influent oil and grease concentration).

Table5. Effectiveness of anoxic selectors in controlling filamentous organisms (Cha et al., 1992)

\begin{tabular}{|l|l|l|}
\hline Organisms & Responsible for & $\begin{array}{l}\text { Effective / Not always } \\
\text { effective }\end{array}$ \\
\hline S. natans & Foaming, filamentous bulking sludge & Effective \\
\hline type 1701 & Filamentous bulking sludge & Effective \\
\hline type $021 \mathrm{~N}^{\text {a }}$ & Filamentous bulking sludge & Effective \\
\hline Thiothrix spp. & $\begin{array}{l}\text { Filamentous sulfur bacterium causes } \\
\text { filamentous bulking sludge. }\end{array}$ & Effective \\
\hline type 0041 & Filamentous bulking sludge & Not always effective \\
\hline type 0675 & Filamentous bulking sludge & Not always effective \\
\hline type 0092 & Filamentous bulking sludge & Not always effective \\
\hline N. limicola & Filamentous bulking sludge & Effective \\
\hline H. hydrossis & Filamentous bulking sludge & Effective \\
\hline M. parvicella & Foaming, filamentous bulking sludge & Not always effective \\
\hline Type 1851 & Filamentous bulking sludge & Effective \\
\hline Nocardia spp. & Foam formation & Effective \\
\hline${ }^{a}$ Not effective when caused by nutrient deficiency & \\
\hline
\end{tabular}

\section{CONCLUSION}

It was observed that the multi-sectional selectors are effective in enhancing the biological nutrient removal as well as bulking control (lower SVIs) if suitable operating conditions are managed. The anaerobic-anoxic-aerobic phases in the SBR system, if properly designed along with controlled wastewater parameters, can behave as a systematic biological treatment system as a whole. However, effective optimization and detailed design parametric studies of selectors in SBR plants should also be done at the pilot-scale level. Biological phosphorus removal is quite complicated because the favorable conditions (enough VFA sources) should be balanced along with $\mathrm{DO}, \mathrm{pH}$, and ORP control in the different sections of advanced SBR systems. Lastly, tertiary treatment and further polishing of treated effluent are needed after the secondary biological treatment to gain the best results of final effluent reuse.

\section{REFERENCES}

I. O. E. Albertson, Technology assessments: Activated Sludge Bioselector Processes. Water Environment and Research Foundation. 2002.

II. N. A. K. Bakti, and R. I. Dick, A model for a nitrifying suspended-growth reactor incorporating intraparticle diffusional limitation. Water Research, 26(12), pp. 1681-1690. 1992. 
III. J. L. Barnard, and M. T. Steichen, Optimizing BNR plant operations for achieving sustainable low Effluent phosphorus. Black and Veatch, Water Environment FederationNutrient Removal 2007.

IV. M. Bhatla, Relationship of activated sludge bulking to oxygen tension. J. Water Pollut. Control Fed., 39(12), pp. 1978-1985. 1967.

V. British Water Pollution Laboratory. Aerobic biological treatment process - Activated sludge process, Ministry of Technology, H.M.S.O., London, England, pp. 70-71. 1969.

VI. A. Broughton, S. Pratt, A. Shilton, Enhanced biological phosphorus removal for high strength wastewater with a low rbCOD:P ratio. Bioresource Technology 99(5), pp. 123641. 2008.

VII. G. Burkhardt, Biological Phosphorus Removal, Operator's Guide. 2012.

VIII. D.K. Cha, D. Jenkins, W.P. Lewis, and W.H. Kido, Process control factors influencing Nocardia populations in activated sludge. Water Env. Research, 64, 37, 1992.

IX. J. Chudoba, J. Blaha, and V. Madera, Control of activated sludge filamentous bulking III. Effect of sludge loading. Water Res., 8, 231, 1974.

X. J. Chudoba, P. Grau, and V. Ottova, Control of activated sludge filamentous bulking - II. Selection of microorganisms by means of a selector, Water Res., 7, 1389, 1973b.

XI. J. Chudoba, V. Ottova, and V. Madera, Control of activated sludge filamentous bulkingI. Effect of hydraulic regime or degree of mixing in an aeration tank. Water Res., 7(8):1163. 1973a.

XII. A.B. Davidson, U.S. Patent No. 2,788,127, filed April 22, 1952, issued April 9, 1957 (apparatus patent). 1957.

XIII. R. N. Dawson, and K. L. Murphy, The temperature dependency of biological denitrification. Water Research. 6(1), pp. 71-83. 1972.

XIV. W. Donaldson, Some notes on the operation of sewage treatment works, Sewage Works J., 4, pp. 48-59. 1932a.

XV. W. Donaldson, Use of activated sludge increasing, Civil Eng., 2(3), pp. 167-169. $1932 b$.

XVI. M. C. Goronszy, and W. W. Eckenfelder, Floc-Load as It Relates to Enzymatic Transfer of Soluble Substrate and Sludge Bulking Control. Water Sci Technol. 20 (1112), pp. 481-484. 1988.

XVII. M. C. Goronszy, Controlling wastewater treatment by monitoring oxygen utilization rates. United States Patent, Patent Number: 5,989,428. 1999.

XVIII. M. C. Goronszy, In Course Notes on "Intermittently operated activated sludge plants." Department of Chemical engineering, University of Queensland, Australia, 1992.

XIX. M. C. Goronszy, G. Demoulin, and M. Newland, Aerated denitrification in full-scale activated sludge facilities. Water Sci. Technol. 34 (1-2), pp. 487-491. 1996.

XX. W. F. Harper, and Jr., D. Jenkins, The Effect of an Initial Anaerobic Zone on the Nutrient Requirements of Activated Sludge. Water Environment Research, 75 (3), pp. 216-224, 2003.

XXI. B.A. Heide, and A. Pasveer, Oxidation ditch: prevention and control of filamentous sludge. $\mathrm{H}_{2} \mathrm{O}$. pp. 7-373. 1974.

XXII. S.H. Isaacs, and M. Henze, Controlled carbon source addition to an alternating nitrification-denitrification wastewater treatment process including biological $\mathrm{P}$ removal. Wat Res. 29, pp. 77-89. 1994 
XXIII. A. Khursheed, R. Z. Gaur, M. K. Sharma, V. K. Tyagi, A. A. Khan, and A. A. Kazmi, Dependence of enhanced biological nitrogen removal on carbon to nitrogen and rbCOD to sbCOD ratios during sewage treatment in sequencing batch reactor. Journal of Cleaner Production, 171, pp. 1244-1254, 2018.

XXIV. D. S. Kim, N. S. Jung, and Y. S. Park, Characteristics of nitrogen and phosphorus removal in SBR and SBBR with different ammonium loading rates. Korean J. Chem. Eng., 25, pp. 793-800. 2008.

XXV. J. Koller, Comparison of some activated sludge modifications. M.S. Thesis, Department of Water Technology, Institute of Chemical Technology, Prague, Czechoslovakia. 1966.

XXVI. S.S. Magdum, V. Kalyanraman, and S. K. Varigala, Evaluation of Sequential Batch Reactor (SBR) Cycle Design to Observe the Advantages of Selector Phase Biology to Achieve Maximum Nutrient Removal. International Journal of Scientific Research in Environmental Sciences. 2015

XXVII. N. Majed, and A. Z. Gu, Impact of Influent Carbon to Phosphorus Ratio on Performance and Phenotypic Dynamics in Enhanced Biological Phosphorus Removal (EBPR) System - Insights into Carbon Distribution, Intracellular Polymer. 2019.

XXVIII. Metcalf and Eddy, Wastewater Engineering Treatment, Disposal, and Reuse. Tata Mc Graw- Hill publication Co., New Delhi, 2003.

XXIX. T. M. Mino, M. C. M. Van Loosdrecht, and J. J. Heijnen, Microbiology and biochemistry of the enhanced biological phosphate removal process Wat. Res 32 (11), pp. 3193-3207, 1998.

XXX. V. Naidoo, and C. A. Buckley, Municipal wastewater characterisation: Application of denitrification batch tests. WRC Report No. 820/1/00, 2011.

XXXI. A. Oehmen, P. C. Lemos, G. Carvalho, Z. Yuan, J. Keller, L. L. Blackall, and M. A. M. Reis, Advances in enhanced biological phosphorus removal: From micro to macro scale. Water Res. 41(11), pp. 2271-2300. 2007.

XXXII. R.W. Okey, Private communication on the bioselector performance of Nestle's plants in Brazil. 1997.

XXXIII. J.C. Palm, D. Jenkins, and D. S. Parker, Relationship between organic loading, dissolved oxygen concentration and sludge settleability in the completely mixed activated sludge process, J. Water Pollut. Control Fed., 52, 2484. 1980

XXXIV. D. Parker, R. Appleton, J. Bratby, and H. Melcer, Anoxic or anaerobic selectors: which is better? Proceedings of the Water Environment Federation. 2003.

XXXV. A. Pasveer, A case of filamentous activated sludge, J. Water Pollut. Control Fed., 41(7), pp. 1340-1352. 1969.

XXXVI. Phosphorus Treatment and Removal Technologies. Minnesota Pollution Control Agency. 2006.

XXXVII. A. R. Pitman, Design considerations for nutrient removal activated sludge plants. Water Sci. Technol., 43 (4-6), pp. 781-191.1991.

XXXVIII. S. Puig, L1. Corominas, M. D. Balaguer, and J. Colprim, Biological nutrient removal by applying SBR technology in small wastewater treatment plants: carbon source and C/N/P ratio effects. Water Science and Technology. 55 (7): 135-141. 2007.

XXXIX. C. W. Randall, J. L. Barnard, and H. D. Stensel, Design and Retrofit of Wastewater Treatment Plants for Biological Nutrient Removal. Volume 5, Water Quality Management Library. 1992.

XL. J. H. Rensink, New approach to preventing bulking sludge, J. Water Pollut. Control Fed., 46, 1888, 1974 
XLI. B. E. Rittman, and W. E. Langeland, Simultaneous denitrification with nitrification in single-channel oxidation ditches. JWPCF. 57(4), pp. 300- 308, 1985.

XLII. Ron Trygar, Nitrogen control in wastewater treatment plants, $2^{\text {nd }}$ edition. CET University of Florida TREEO Center, 2009.

XLIII. R. A. Ryder, Dissolved oxygen control in activated sludge. In: Proc. of the 24th Ind. Waste Conf., Purdue University, Lafayette, Ind., pp. 238-253. 1973.

XLIV. SFC Environmental technologies Pvt ltd., 2020

XLV. M. Singh, and R. K. Srivastava, Sequencing batch reactor technology for biological wastewater treatment: a review. Asia-Pac. J. Chem. Eng., 6, pp. 3-13. 2010.

XLVI. V. B. D. Skerman, and I. C. MacRae, The influence of oxygen availability on the degree of nitrate reduction by pseudomonas denitrificans. Canadian Journal of Microbiology 3(3), 1957.

XLVII. E. Vives, Cellular uptake of the Tat peptide: an endocytosis mechanism following ionic interactions. Journal of Molecular Recognition, 2003.

XLVIII. F. Wang, S. Lu, Y. Wei, and M. Ji, Characteristics of aerobic granule and nitrogen and phosphorus removal in a SBR. J. Hazard. Mater. , 164, pp. 1223-7. 2009.

XLIX. J. Wanner, and P. Grau, Filamentous bulking in nutrient removal activated sludge systems, Water Science Technology, 20, 1, 1988.

L. G. Xin, H. L. Gough, and H. D. Stensel, Effect of Anoxic Selector Configuration on Sludge Volume Index Control and Bacterial Population Fingerprinting. Water Environment Research. Biological Treatment, 80 (12), pp. 2228-2240. 2008. 